\title{
Low benthic impact of an offshore mussel farm in Îles-de-la-Madeleine, eastern Canada
}

\author{
Élise Lacoste $^{1, *}$, Annick Drouin ${ }^{1}$, Andrea M. Weise ${ }^{1}$, Philippe Archambault ${ }^{2}$, \\ Christopher W. McKindsey ${ }^{1}$
}

${ }^{1}$ Maurice Lamontagne Institute, Fisheries and Oceans Canada, Mont-Joli, Canada
${ }^{2}$ Département de biologie, UMI Takuvik, Université Laval, Québec, Canada

\begin{abstract}
Ensuring sustainable management of the emerging open-ocean aquaculture industry requires an understanding of how this activity interacts with the surrounding environment. We examined the effects of an offshore mussel farm on sedimentation rates, sediment sulfide levels and macro-infaunal communities near Îles-de-la-Madeleine, eastern Canada. The farm had been in production for $6 \mathrm{yr}$ and is located in a deep $(19 \mathrm{~m})$ high-energy environment. The impacts were examined for 2 densities of mussels (standard and double) and at different periods of the year. There was no sign of excessive organic enrichment or a clear pattern of a significantly modified benthic environment. However, some organisms likely benefited from the biodeposits and fall-off of mussels (and associated communities), and the farm presumably induced heterogeneity in the distribution of infaunal communities, likely due to variation in the dispersion of biodeposits caused by the structure of the longlines and local hydrodynamics. Annual and interannual variability appear stronger than the influence of the farm, and no detrimental effects are suspected. This study provides baseline information about the limited documented effects of open-ocean bivalve aquaculture on the benthic environment.
\end{abstract}

KEY WORDS: Aquaculture effects $\cdot$ Mytilus edulis $\cdot$ Offshore sites $\cdot$ Sediment $\cdot$ Benthic infaunal communities $\cdot$ Spatial variations

\section{INTRODUCTION}

While capture fisheries have been relatively stable since the late 1990s, aquaculture continues to be one of the most rapidly growing food industries, with the potential to meet the needs and demands of an increasing human population (FAO 2016). The expansion of coastal aquaculture is becoming increasingly constrained as favorable nearshore sites in many countries are often already being used for aquaculture or other activities. Thus, this industry must often compete for space with other resource users and is therefore an important player in integrated coastal zone management (Jansen et al. 2016, Gentry et al. 2017). In this context, the open ocean offers tremendous potential areas in which to increase global aquaculture production. To date, off-

${ }^{*}$ Corresponding author: eliz.lacoste@gmail.com shore production (see Holmer 2010 for a definition of 'offshore' conditions) remains limited relative to other forms of aquaculture (e.g. coastal, estuarine), and this new use of the open-ocean area still presents significant challenges, including appropriate aquaculture site selection. With a predicted worldwide expansion of open-ocean aquaculture, there will also be increasing concerns about the environmental impacts of this industry (Holmer 2010).

The most obvious effect of bivalve aquaculture on the environment, i.e. the accumulation of biodeposits on the bottom under culture sites, induces organic enrichment of benthic sediments, affects the diversity and structure of benthic communities, and modifies benthic biogeochemical cycling (e.g. Callier et al. 2008, 2009, Gaertner-Mazouni et al. 2012, Drouin et al. 2015). Typically, the accumulation and decompo-

(c) P. Archambault and Fisheries and Oceans Canada 2018. Open Access under Creative Commons by Attribution Licence. Use, distribution and reproduction are unrestricted. Authors and original publication must be credited. 
sition of biodeposits from cultured bivalves affect benthic communities according to the Pearson \& Rosenberg (1978) model of organic enrichment, with a progressive appearance of opportunistic species (e.g. Capitella spp.) directly under and in the vicinity of aquaculture facilities. Many studies over the past $30 \mathrm{yr}$ have reported results on this topic for different cultivated species and ecosystems (see reviews by Newell 2004, Forrest et al. 2009, McKindsey et al. 2011). To date, most work on determining the impact of cultivated bivalves on the benthic compartment has concentrated on coastal systems, while the impacts of open-ocean farms remain largely understudied (but see Danovaro et al. 2004, Fabi et al. 2009). Studies of finfish aquaculture in open-ocean areas generally show less accumulation of organic matter in the sediments and less disturbed benthic communities compared to sheltered and shallower sites (Aguado-Giménez \& García-García 2004, Grizzle et al. 2014). The benthic impact of bivalve aquaculture in offshore areas is also expected to be less than that in shallow water due to higher current velocities and greater depths (Giles et al. 2009, Weise et al. 2009), although it may have a larger-scale but more diffuse effect. With the potential expansion of open-ocean bivalve farming, substantial research is needed to assess its impacts on the benthic environment and to define relevant indicators to monitor its potential ecological effects (Froehlich et al. 2017).

Since the mid 1980s, mussel farming (mainly blue mussel Mytilus edulis) in Îles-de-la-Madeleine was developed exclusively within the lagoons. However, the limited extent of areas that are deep enough to accommodate traditional longline mussel culture inside the lagoons has forced producers and managers to consider offshore sites to further develop the industry. A 2002 pilot project showed the viability of mussel culture in Baie de Plaisance, about $4 \mathrm{~km}$ off the coast (Werstink 2007, Bourque \& Myrand 2014). The site meets most criteria for the definition of an 'offshore' site (i.e. $>3 \mathrm{~km}$ from the coast with minimum visual impact and subject to strong winds, currents and waves; however, it is only ca. $20 \mathrm{~m}$ deep; see Holmer 2010) and is therefore considered as such.

Information on the environmental effects of an experimental mussel farm in the area was obtained by sampling benthic conditions in 2002, prior to the addition of longlines, and in 2005, 3 yr after starting the experimental farm. No evidence of farm-related effects on the benthic environment was observed (Tita \& Bourque 2007). Following this experimental culture phase, a commercial farm started operations in the area. For this culture to be managed in a sus- tainable manner, it was suggested that the organic loading and subsequent impact on benthic conditions should be monitored to ensure that good ecological status is maintained.

Thus, a study was performed in 2013 to evaluate the benthic conditions under and around the offshore mussel farm 7 yr after the start of commercial activities. Sedimentation rates, sulfide concentration and benthic macro-infaunal communities were evaluated below and around 2 densities of mussels established in the farm and compared to values from reference sites to assess potential benthic impacts of the farm. Seasonal variation was considered by sampling during several periods of the year and to test the hypothesis that poor weather conditions late in the growing season may act to 'reset' the benthic system due to scouring from wave/swell action.

\section{MATERIALS AND METHODS}

\section{Study site and sampling stations}

The study was located about $4 \mathrm{~km}$ off of Îles-de-laMadeleine ( $\left.47^{\circ} 37^{\prime} \mathrm{N}, 61^{\circ} 31^{\prime} \mathrm{W}\right)$ in Baie de Plaisance, Québec, eastern Canada (Fig. 1). This area is characterized by low ( $0.5 \mathrm{~m}$ maximum) tidal amplitude (Koutitonsky et al. 2002) and is exposed to high currents and waves. Depth averages $19 \mathrm{~m}$ in the mussel lease, and the bottom is characterized by a fine sandy substrate. The mussel lease covers an area of approximately $2.5 \mathrm{~km}^{2}$ and consists of 203 longlines with $3 \mathrm{~m}$ long mussel socks, spaced by $50 \mathrm{~cm}$ and suspended at about $9 \mathrm{~m}$ below the surface. This design leads to a final density of ca. 1 longline per hectare of farm. The $100 \mathrm{~m}$ longlines are oriented in rows along a northeast-southwest direction, and longline rows are spaced every $50 \mathrm{~m}$. Mussels are seeded in the growing site each year in the autumn (OctoberNovember) and usually reach a harvestable size of $55 \mathrm{~mm}$ shell length late the next autmun ( 18 mo old mussels). As a consequence of the growing period extending over more than $1 \mathrm{yr}$, a maximum of $50 \%$ of the farm area can be attributed to a given cohort. The farm has been in operation since 2007 and has an annual production of ca. $200 \mathrm{t}$.

Several transects (50 m long) were installed under longlines with 1 of 2 densities of mussels (standard and double density, hereafter D and DD), so that their middle was directly below the mussel line and perpendicular to them. Five stations were established along each transect, at $0 \mathrm{~m}$ (directly below longlines) and at 10 and $25 \mathrm{~m}$ to each side of them, the $25 \mathrm{~m}$ dis- 


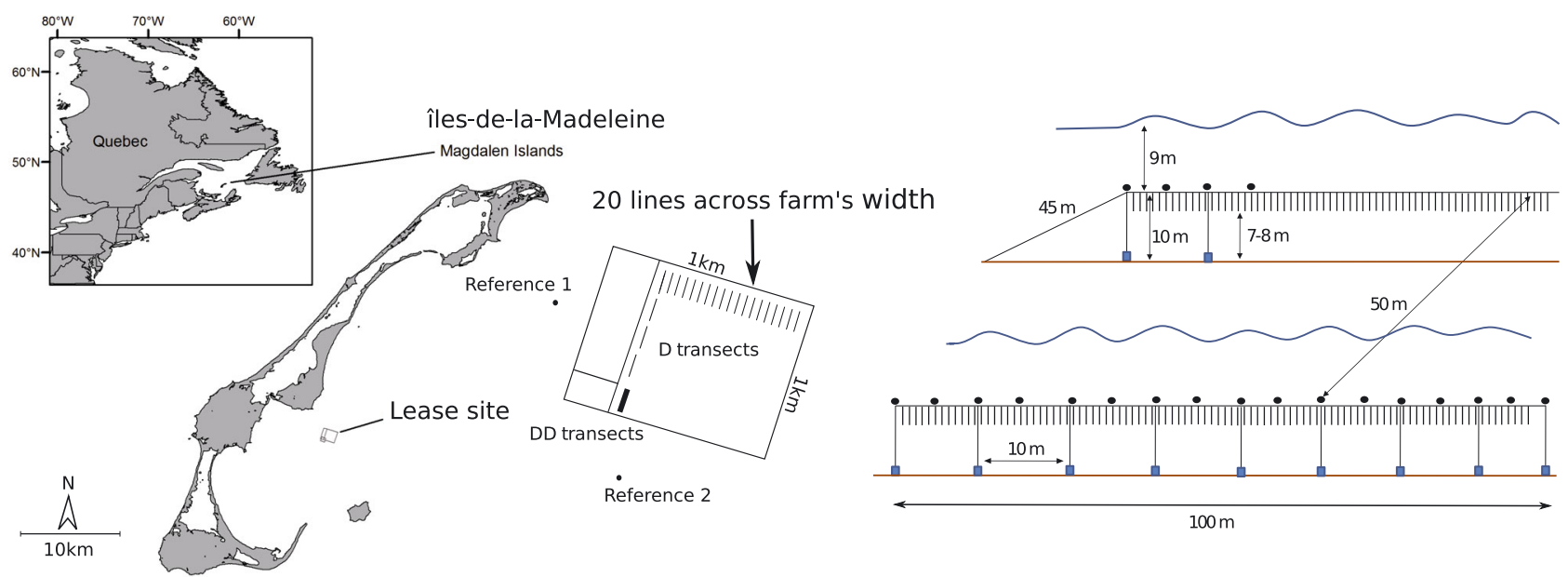

Fig. 1. Left: location of the study site. Transects were randomly positioned under 3 longlines of standard density (D transects) and 1 longline of double density (DD transects). Reference stations were positioned $500 \mathrm{~m}$ away from the lease site. Right: typical farm layout (modified from Guyondet et al. 2015)

tance being directly between adjacent longlines. Two sites served as references, located $500 \mathrm{~m}$ south and west of the longlines (Fig. 1). In June 2013, sedimentation was measured along one transect under the DD longline and at the 2 reference stations. In August 2013, sedimentation rate, sulfide concentration and macro-infaunal communities were evaluated along 2 transects deployed under the DD longline and along 2 transects installed under randomly selected D longlines in the farm (3 transects for the sedimentation rate). As fall storm events may 'reset' the benthic system, sampling was also performed in October 2013 for comparison with the spatial patterns of benthic conditions observed prior to storm events. At this time, sedimentation rate was measured along 4 transects (2 D and 2 DD) and macro-infauna and sulfide concentrations were recorded around the DD longline along 1 transect. Reference stations were also sampled in August and October 2013.

\section{Sedimentation rates}

Depositional footprints around the longlines were assessed using sediment traps made of $50 \mathrm{~cm}$ lengths of $5 \mathrm{~cm}$ diameter PVC pipes with one end enclosed by transparent PVC and affixed to metal bases on the bottom (see Callier et al. 2006 for a full description). Traps were deployed in pairs at each distance station along transects and at reference stations and retrieved after $24 \mathrm{~h}$, except in October, when the traps were removed after $48 \mathrm{~h}$ because of bad weather conditions. Contents of sediment traps were kept frozen $\left(-20^{\circ} \mathrm{C}\right)$ until processed. In the laboratory, trap con- tents were filtered through pre-combusted and preweighed glass fiber filters (Whatman GF/F, $0.7 \mu \mathrm{m}$ ). Filters with sediments were rinsed with ammonium formate, dried at $65^{\circ} \mathrm{C}$ to constant weight (at least $72 \mathrm{~h}$ ) and weighed. The percent organic matter $(\% \mathrm{OM})$ in the sedimented material was calculated as the total weight loss upon ignition at $500^{\circ} \mathrm{C}$ for $6 \mathrm{~h}$.

Two acoustic Doppler current profilers (ADCP, SonTek) were deployed in the vicinity of the farm from June to October 2013 to record water velocity and direction every $30 \mathrm{~min}$ at $1 \mathrm{~m}$ intervals over the whole water column.

\section{Biodeposit production and settling velocities}

Biodeposition by mussels was measured on 2 occasions during the study, for 3 size classes of mussels (ca. 36, 49 and $53 \mathrm{~mm}$ length) that represented the mussel sizes in the farm at the time of study, with the objective to estimate a global biodeposit production at the farm scale. Production was measured in situ by placing individual mussel socks (120 to 290 mussels per sock) above large sediment traps and collecting material after 1 d (see McKindsey et al. 2009 for detailed method). Biodeposition was calculated as the amount of material collected in sediment traps with mussels minus the average sedimentation obtained in shell controls, and then divided by the number of individuals in each trap to obtain an average biodeposit production per individual.

To estimate the dispersal of mussel biodeposits in Baie de Plaisance, the sinking velocity of faecal pellets was also measured. The sinking speed of 50 ran- 
domly chosen individual faecal pellets was observed and recorded in a cylindrical glass sinking column (45 cm height, $10.5 \mathrm{~cm}$ diameter) as described in Callier et al. (2006).

\section{Sediment characteristics}

Surficial sediments were collected by divers using 5 replicate sediment cores $(10 \mathrm{~cm}$ diameter, $15 \mathrm{~cm}$ depth) at each distance station along D and DD transects in August and along the DD transect in October; 5 cores were similarly collected at each date at the reference stations. Sub-samples from the top $0-2 \mathrm{~cm}$ were collected by lateral insertion of $5 \mathrm{ml}$ cutoff syringes through the side of the core via predrilled holes covered by duct tape to determine total free sulfides (TFS) and \%OM. Samples were stored at $4^{\circ} \mathrm{C}$ and analyzed within $6 \mathrm{~h}$ using standard ion selective electrode methods (detailed methodology is provided in Callier et al. 2007). TFS was determined using an Orion silver/silver sulphide electrode (Orion 9616BNWP) filled with Optimum Results A solution (Orion 900061). The \%OM in surface sediments was calculated as the weight loss of dried material combusted at $500^{\circ} \mathrm{C}$ for $6 \mathrm{~h}$.

\section{Macro-infaunal communities}

Sediment core samples were sieved through a $0.5 \mathrm{~mm}$ mesh and retained organisms were preserved in $10 \%$ buffered formalin. Macro-infauna were identified to the lowest taxonomic level possible in the laboratory and counted. Samples were characterized in terms of total abundance $(N)$ and diversity indices, i.e. total number of taxa $(S)$, Simpson's inverse index $\left(D_{2}\right)$ and evenness $(E)$.

\section{Statistical analysis}

Community characteristics (diversity indices), sedimentation rates and sulfide levels were compared among distances using ANOVA with distance as a fixed factor and transect as a random factor, for each mussel density and period separately. When a significant difference was observed, multiple comparisons were performed using Dunnett's contrasts between all distances and the reference station and Tukey contrasts between all other distances along all transects (Lomax \& Hahs-Vaughn 2013). Assumptions of ANOVA were assessed visually (Quinn \& Keough
2002) and using Bartlett's test to verify the homoscedasticity of residuals. Transformations were applied for sedimentation rate (log) and \%OM (square root) in June. Benthic macro-infaunal community data were analysed using raw data for each core, and taxa observed only once were excluded from the analyses (Clarke \& Warwick 2001). Community structure was analysed with non-parametric multivariate analysis of variance (PERMANOVA), including a posteriori pairwise comparisons, and visualised using nonmetric multidimensional scaling (nMDS). Distance matrices were calculated using Bray-Curtis distance on fourth-root-transformed data, and homogeneity of multivariate dispersion was verified using the $R$ version (in the package vegan) of the PERMDISP routine (Anderson et al. 2008). Taxa that contributed the greatest to differences in community structure between treatments were identified using similarity percentage (SIMPER) routines (Clarke 1993) based on the Bray-Curtis dissimilarity index. Analyses were performed using R 3.3.2 (2016) using the vegan and RVAideMemoire packages for multivariate analysis.

\section{RESULTS}

\section{Hydrological conditions}

The daily mean current speed (averaged on the 6-15 m cells where mussel socks were deployed) averaged $8.5 \mathrm{~cm} \mathrm{~s}^{-1}$, with a minimum speed of $4 \mathrm{~cm}$ $\mathrm{s}^{-1}$ and a maximum speed of $17 \mathrm{~cm} \mathrm{~s}^{-1}$ over the study period. The monthly mean speed was at a minimum in June $\left(7 \mathrm{~cm} \mathrm{~s}^{-1}\right)$ and at a maximum in August $(9 \mathrm{~cm}$ $\mathrm{s}^{-1}$ ). The orientation of the principal current was aligned with the orientation of the longlines, i.e. NE-SW (Fig. 1).

\section{Sedimentation rates}

Sedimentation rates in June were several orders of magnitude greater compared to those measured in August and October (Fig. 2). The highest rates were measured directly under the DD mussel line in June $\left(143.3 \pm 23.1 \mathrm{~g} \mathrm{~m}^{-2} \mathrm{~d}^{-1}\right.$ at the $0 \mathrm{~m}$ station) compared to reference stations $\left(7.7 \pm 1.5 \mathrm{~g} \mathrm{~m}^{-2} \mathrm{~d}^{-1}\right.$; Fig. 2, Table 1$)$. Sedimentation in August was also greatest directly below the DD line $(0 \mathrm{~m})$ and decreased away from that position (Fig. 2), but the only significant difference was observed between the reference and the 0 and $10 \mathrm{~m}$ stations (Table 1). Sedimentation rate under the D lines in August was removed from the analysis 

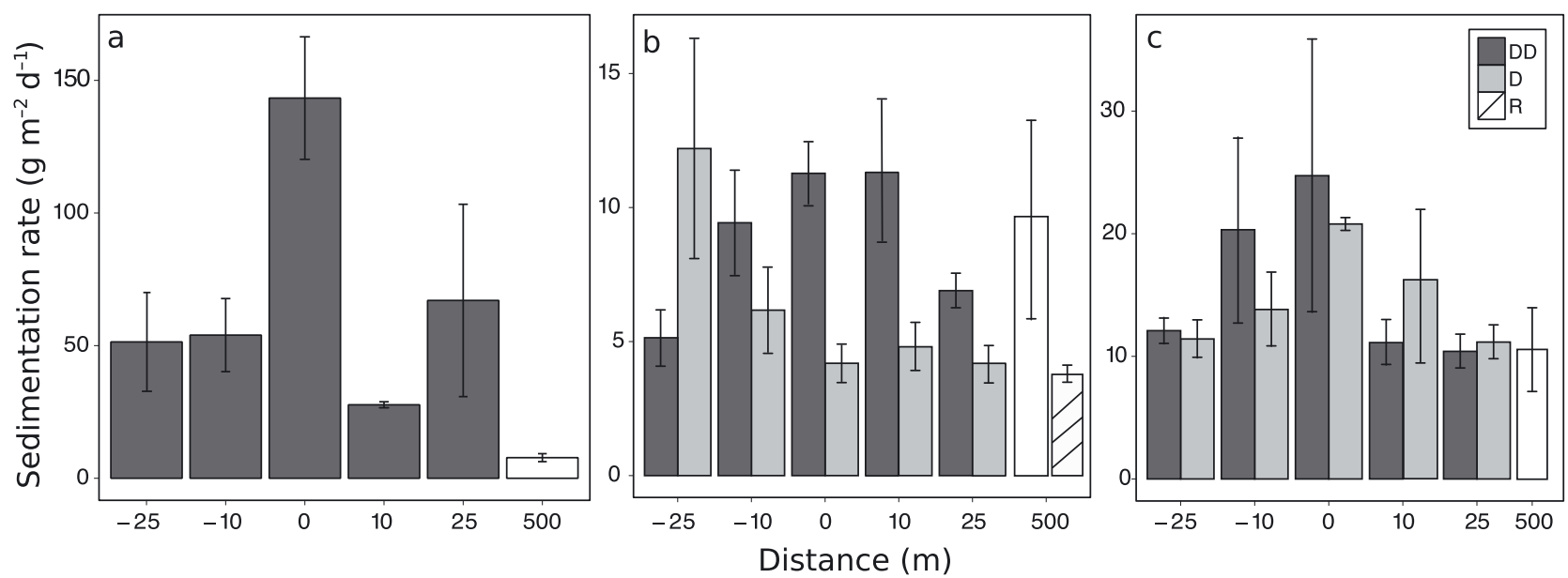

Fig. 2. Mean ( \pm SE) sedimentation rate recorded in (a) June, (b) August and (c) October 2013 below and around mussel lines with 2 densities of mussels (DD: double; D: standard) and at the reference stations (R). References stations in August correspond to 2 sampling dates: 6-7 August (white), which were sampled simultaneously with stations under the D lines; stations under the DD line and R stations (with white stripes) were sampled on 14 August

since results were somewhat unreliable due to high variations between 2 sampling days. Sedimentation rates in October did not differ significantly between reference and all stations under the D and DD lines.

The $\% \mathrm{OM}$ of sedimented material was below $5 \%$ at all stations along the DD lines in June and significantly different from that of the reference station (13\%; Fig. 3, Table 1). With the exception of the 0, 10 and $25 \mathrm{~m}$ stations under the $\mathrm{D}$ lines in August (\%OM $\sim 16 \%$ ), \%OM did not differ significantly between reference and farm locations in August and October (Tables 1 \& 2), with values ranging between $~ 8 \%$ and $\sim 14 \%$.

Organic sediment deposition was consistently very low $\left(<4 \mathrm{~g} \mathrm{~m}^{-2} \mathrm{~d}^{-1}\right)$ and followed the same pattern as total sedimentation, with the highest value recorded under the DD mussel line in June $\left(3.9 \pm 0.1 \mathrm{~g} \mathrm{~m}^{-2} \mathrm{~d}^{-1}\right.$ at the $0 \mathrm{~m}$ station). Values of organic sedimentation for all others dates and stations were lower than $3 \mathrm{~g}$ $\mathrm{m}^{-2} \mathrm{~d}^{-1}$.

\section{Biodeposit production and settling velocity}

On average, biodeposit production per individual (for the 3 combined size classes) was $25.7 \pm 2.4 \mathrm{mg}$ $\mathrm{d}^{-1}$ ind. $^{-1}$, with larger mussels producing greater quantities of biodeposits than smaller mussels. However, when expressed per unit biomass, this corresponds to mean biodeposition rates of $35.8 \pm 20.7$ and $97.2 \pm 29.8 \mathrm{mg} \mathrm{d}^{-1} \mathrm{~g}^{-1}$ tissue dry weight (DW) for large (mean DW of $0.74 \pm 0.06 \mathrm{~g}$ ) and small (mean DW of $0.2 \pm 0.01 \mathrm{~g}$ ) mussels, respectively. Average biodeposit \%OM was $19 \%$.

Table 1. Results of ANOVA evaluating the effect of distance on sedimentation rate and organic matter content (\%OM) in sediment traps under the double density longline in June, August and October 2013. Bold values highlight significant effects at $\mathrm{p}<0.05$

\begin{tabular}{|c|c|c|c|c|c|c|c|c|c|c|c|c|}
\hline \multirow{2}{*}{ Source of variation } & \multicolumn{4}{|c|}{ June } & \multicolumn{4}{|c|}{- August } & \multicolumn{4}{|c|}{ - October } \\
\hline & $\mathrm{df}$ & MS & $F$ & $\mathrm{p}$ & $\mathrm{df}$ & MS & $F$ & $\mathrm{p}$ & df & MS & $F$ & $\mathrm{p}$ \\
\hline \multicolumn{13}{|l|}{ Sedimentation rate } \\
\hline Distance & 5 & 5228 & 8.716 & $0.004^{a}$ & 5 & 39.09 & 4.16 & $0.013^{b}$ & 5 & 149.9 & 1.258 & 0.326 \\
\hline Residuals & 8 & 600 & & & 16 & 9.40 & & & 17 & 119.2 & & \\
\hline \multicolumn{13}{|l|}{$\% O M$} \\
\hline Distance & 5 & 0.005 & 5.993 & $0.013^{c}$ & 5 & 0.003 & 2.423 & 0.081 & 5 & 0.0007 & 0.799 & 0.565 \\
\hline Residuals & 8 & 0.00001 & & & 16 & 0.001 & & & 17 & 0.0008 & & \\
\hline
\end{tabular}



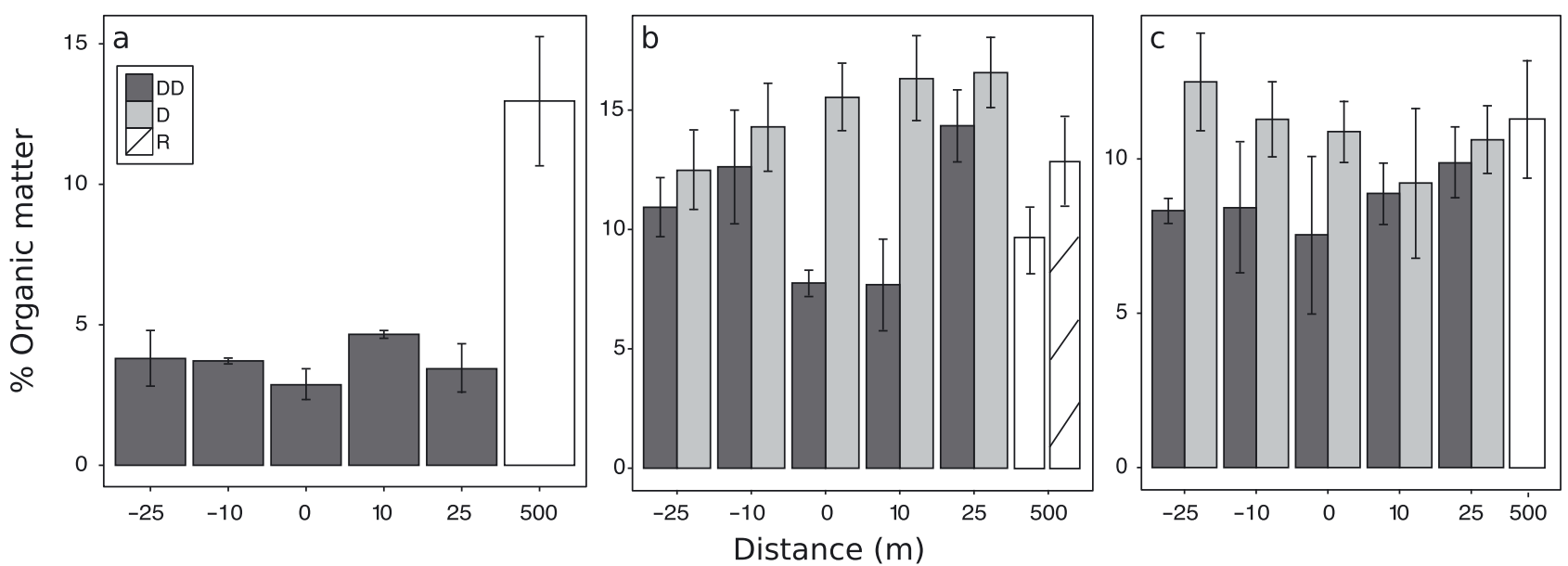

Fig. 3. Mean $( \pm$ SE) organic matter content of sedimented material recorded in (a) June, (b) August and (c) October 2013 under mussel lines with 2 densities of mussels (DD: double; D: standard) and at the reference stations (R). References stations in August correspond to 2 sampling dates: 6-7 August (white), which were sampled simultaneously with stations under the D lines; stations under the DD line and R stations (white with stripes) were sampled on 14 August

Table 2. Results of ANOVA evaluating the effect of distance (fixed factor) on sedimentation rate and organic matter content $(\% \mathrm{OM})$ in sediment traps under standard density mussel lines in August and October. Bold values are significant at $p<0.05$. - : not applicable

\begin{tabular}{|c|c|c|c|c|c|c|c|c|}
\hline \multirow{2}{*}{ Source of variation } & \multicolumn{4}{|c|}{ - August } & \multicolumn{4}{|c|}{ October- } \\
\hline & $\mathrm{df}$ & MS & $F$ & $\mathrm{p}$ & $\mathrm{df}$ & MS & $F$ & $\mathrm{p}$ \\
\hline \multicolumn{9}{|l|}{ Sedimentation rate } \\
\hline Distance & - & - & - & - & 5 & 60.55 & 1.903 & 0.15 \\
\hline Residuals & - & - & & & 16 & 31.81 & & \\
\hline \multicolumn{9}{|l|}{$\% \mathrm{OM}$} \\
\hline Distance & 5 & 0.008 & 2.968 & $0.019^{\mathrm{a}}$ & 5 & 0.0003 & 0.356 & 0.871 \\
\hline Residuals & 56 & 0.0026 & & & 16 & 0.0009 & & \\
\hline
\end{tabular}

(Tukey contrasts, $\mathrm{p}=0.023$ ) and reference stations (Dunett's contrasts, $t=2.97, \mathrm{p}=$ 0.024). Similar values were measured in October with no trends between stations (data not shown). The \%OM of sediment was uniformly low, with values $<1.5 \%$ (Fig. 4B), and did not differ significantly between stations under the $\mathrm{D}(F=0.289$, $\mathrm{p}=0.915)$ or $\mathrm{DD}(F=0.27$, $\mathrm{p}=0.926$ ) mussel lines.
Mussels produced faecal pellets of varying sizes ranging from 1.7 to $13.3 \mathrm{~mm}$ in length and from 0.7 to $1.5 \mathrm{~mm}$ in width. Minimum and maximum sinking velocities were 0.3 and $1.0 \mathrm{~cm} \mathrm{~s}^{-1}$, respectively, and the average sinking velocity was $0.54 \pm$ $0.14 \mathrm{~cm} \mathrm{~s}^{-1}$.

\section{Bottom sediment characteristics}

TFS concentrations were generally below $750 \mu \mathrm{M}$ at all stations, with the highest values recorded from samples from beneath the DD line in August (Fig. 4A). TFS during this month was significantly higher $(F=$ $3.858, \mathrm{p}=0.009)$ directly beneath the DD line $(0 \mathrm{~m}$ station) compared with the $-25 \mathrm{~m}$ and $25 \mathrm{~m}$ stations

\section{Macro-infaunal community characteristics}

Abundance, richness and diversity indices

A total of 145 taxa, 30\% of which were polychaetes, $15 \%$ bivalves and 16\% malacostracans (mainly amphipods), were collected and identified in this study. The 5 dominant taxa were the polychaete Spiophanes bombyx (16\% of all organisms), Echinoidea (9\%), Nematoda (7\%), Podocopida (6\%) and the polychaete Ninoe nigripes $(6 \%)$. The density of these organisms at the $0 \mathrm{~m}$ and reference stations is given in Table 3 for each season and mussel line density.

Measured community characteristics $(S, N, E$ and $D_{2}$ ) did not differ between stations under the stan- 


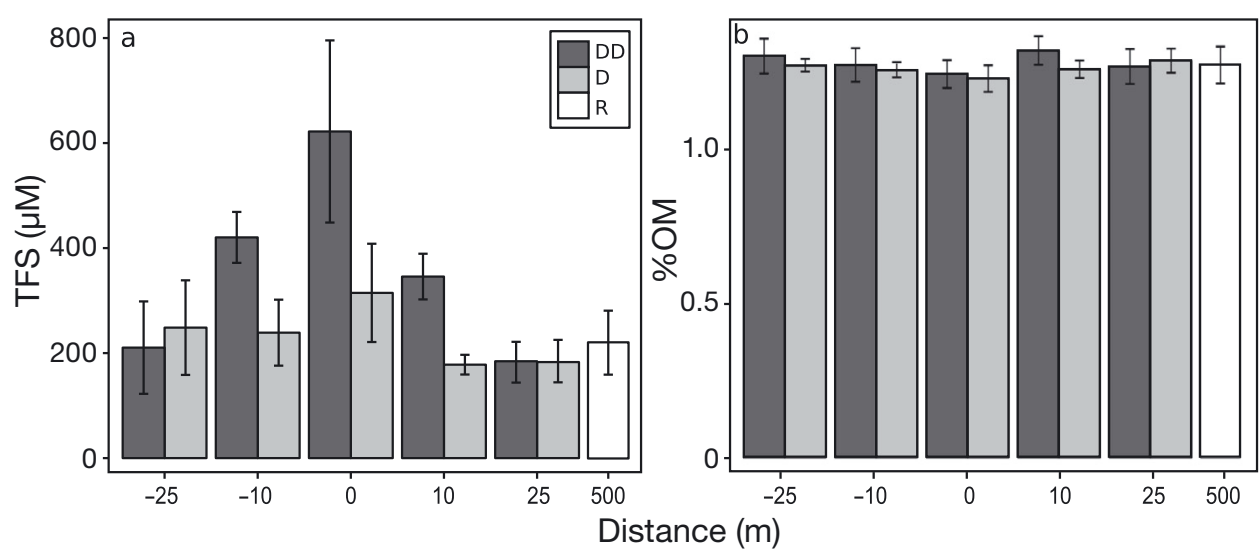

Fig. 4. Mean $( \pm \mathrm{SE})(\mathrm{a})$ total free sulfide concentrations (TFS) and (b) sediment organic matter content (\%OM) recorded in August 2013 under double density (DD) and standard density (D) mussel longlines and at reference stations (R)

tion of distance from longlines for both D and DD lines and in both August and October (Table 5). Pairwise comparisons showed no significant differences between the reference stations ( $p>0.5)$, whereas community structure differed significantly between most stations along both the D and DD transects (Table 5), indicating greater small-scale variation in community structure under the lines and a more homogeneous structure further from the farms (reference stations). SIMPER analysis showed that dissimilarity between communities at

dard density mussel longlines and the reference stations (Table 4, Fig. 5). In summer, taxonomic richness $(S)$ at the $0 \mathrm{~m}$ station below the DD line was significantly lower compared to the $-25 \mathrm{~m}$ and reference stations, and $D_{2}$ was higher at the reference stations than at the 10 and $-10 \mathrm{~m}$ stations (Table 4, Fig. 5). In October, richness and abundance $(N)$ did not differ between stations along the transect and the reference stations, but abundance at the $25 \mathrm{~m}$ station was significantly higher than that at the 0 and $-25 \mathrm{~m}$ stations (Table 4, Fig. 5). $D_{2}$ and $E$ were lower at the reference stations than at the $0 \mathrm{~m}$ station (Table 4 , Fig. 5).

\section{Community structure}

A priori comparison of community structure (Fig. 6) shows a clear distinction between August and October and between reference stations and stations under mussels for both months. Statistical differences were detected among community structure as a func-

Table 3. Mean density (ind. $\mathrm{m}^{-2}$ ) of the 5 dominant taxonomic groups at the $0 \mathrm{~m}$ station (directly under the longlines; D: standard density; DD: double density) and at reference stations (R) in August and October 2013

\begin{tabular}{|lcccccc|}
\hline \multirow{2}{*}{ Taxon } & \multicolumn{3}{c}{ August } & \multicolumn{2}{c|}{ October } \\
\cline { 2 - 5 } & D & DD & R & DD & R \\
\hline Spiophanes bombyx & 3096 & 1796 & 2025 & 2115 & 5134 \\
Echinoidea & 1656 & 1376 & 318 & 739 & 89 \\
Nematoda & 1758 & 1146 & 1057 & 484 & 1783 \\
Podocopida & 1210 & 815 & 994 & 1172 & 675 \\
Ninoe nigripes & 1427 & 471 & 2166 & 739 & 3134 \\
\hline
\end{tabular}

$0 \mathrm{~m}$ and those at the reference stations were mostly related ( $70 \%$ of cumulative dissimilarity) to differing abundances of 12 and 22 taxa in August and October, respectively (Table 6). The same pattern was observed for both dates and mussel line densities, where Ninoe nigripes, Diastylis polita, Nucula delphinodonta and Thraciidae spp. were less abundant directly under mussel lines compared with at reference stations. In contrast, the gastropod Ilyanassa trivittata and Echinoidea were more abundant under mussel lines (and at intermediate distances for echinoids) compared to reference stations. In October, the difference between the $0 \mathrm{~m}$ and reference stations was mainly due to the greater abundance of mussels recorded at the $0 \mathrm{~m}$ station, and as likely due to an important fall-off after bad weather conditions. Some other taxa showed the contrasting pattern, being more abundant either at the $0 \mathrm{~m}$ station or at reference stations, depending on the transect (e.g. S. bombyx, Pholoe longa, Nematoda spp.). An example of SIMPER results is given in Table 6, comparing species abundance between the $0 \mathrm{~m}$ and reference stations in August.

\section{DISCUSSION}

Environmental impacts of shellfish aquaculture on benthic conditions have been shown to range from low (Danovaro et al. 2004, Mallet et al. 2006), to slight (McKindsey et al. 2012, Dimitriou et al. 2015) to severe (Dahlbäck \& Gunnarsson 1981, Stenton- Dozey et al. 2001, Hargrave et al. 2008, Cranford et al. 2009). The degree of environmental impact is likely related to both the site (background enrichment, sediment 
Table 4. Results of ANOVAs testing the effect of distance $(-25,-10,0,10$ and $25 \mathrm{~m}$, and reference stations) on abundance ( $N)$, richness $(S)$, evenness $(E)$ and Simpson's inverse $\left(D_{2}\right)$ indices. D: standard density; DD: double density

\begin{tabular}{|c|c|c|c|c|c|c|c|c|c|c|c|c|c|}
\hline & \multirow{2}{*}{$\begin{array}{l}\text { Source of } \\
\text { variation }\end{array}$} & \multicolumn{4}{|c|}{ Aug D } & \multicolumn{4}{|c|}{ - Aug DD } & \multicolumn{4}{|c|}{ Oct DD } \\
\hline & & $\mathrm{df}$ & MS & $F$ & $\mathrm{p}$ & $\mathrm{df}$ & MS & $F$ & $\mathrm{p}$ & $\mathrm{df}$ & MS & $F$ & $\mathrm{p}$ \\
\hline \multirow[t]{3}{*}{$N$} & Distance & 5 & 3129 & \multirow[t]{3}{*}{1.759} & \multirow[t]{3}{*}{0.137} & 5 & 4057 & \multirow[t]{3}{*}{1.434} & \multirow[t]{3}{*}{0.227} & 5 & 5387 & \multirow[t]{3}{*}{4.506} & \multirow[t]{3}{*}{$0.004^{b}$} \\
\hline & Transect & 1 & 390.2 & & & 1 & 1354 & & & & & & \\
\hline & Residuals & 53 & 1779 & & & 53 & 2828 & & & 29 & 1196 & & \\
\hline \multirow[t]{3}{*}{$S$} & Distance & 5 & 2 & \multirow[t]{3}{*}{0.207} & \multirow[t]{3}{*}{0.958} & 5 & 49.39 & \multirow[t]{3}{*}{2.796} & \multirow[t]{3}{*}{$0.026^{\mathrm{a}}$} & 5 & 20.14 & \multirow[t]{3}{*}{1.447} & \multirow[t]{3}{*}{0.237} \\
\hline & Transect & 1 & 91.27 & & & 1 & 1.67 & & & & & & \\
\hline & Residuals & 53 & 9.64 & & & 53 & 17.66 & & & 29 & 13.92 & & \\
\hline \multirow[t]{3}{*}{$E$} & Distance & 5 & 0.01 & \multirow[t]{3}{*}{1.285} & \multirow[t]{3}{*}{0.284} & 5 & 0.03 & \multirow[t]{3}{*}{3.721} & \multirow[t]{3}{*}{$0.006^{\mathrm{c}}$} & 5 & 0.034 & \multirow[t]{3}{*}{5.597} & \multirow[t]{3}{*}{$0.001^{d}$} \\
\hline & Transect & 1 & 0.01 & & & 1 & 0.00 & & & & & & \\
\hline & Residuals & 53 & 0.01 & & & 53 & 0.63 & & & 29 & 0.006 & & \\
\hline \multirow[t]{3}{*}{$D_{2}$} & Distance & 5 & 4.92 & \multirow[t]{3}{*}{1.341} & \multirow[t]{3}{*}{0.261} & 5 & 15.47 & \multirow[t]{3}{*}{3.306} & \multirow[t]{3}{*}{$0.011^{d}$} & 5 & 8.847 & \multirow[t]{3}{*}{3.343} & \multirow[t]{3}{*}{$0.017^{\mathrm{f}}$} \\
\hline & Transect & 1 & 3.52 & & & 1 & 0.63 & & & & & & \\
\hline & Residuals & 53 & 3.66 & & & 53 & 4.68 & & & 29 & 2.646 & & \\
\hline & ess at $0 \mathrm{~m}$ & iifi & atly lo & r than & at at & c & ions & $=0.0$ & ) and th & $5 \mathrm{~ms}$ & ion $(p$ & $0.013)$ & \\
\hline & dance at & & ion is & gnifica & yre & 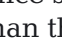 & at $t$ & $0 \mathrm{~m}(\mathrm{p}$ & $=0.048)$ & -25 & $p=0$. & statio & \\
\hline & hess at the & stati & is sign & ficantly & igher th & hat a & the 10 & $\mathrm{n}(\mathrm{p}=0$ & 012) anc & $\mathrm{m}$ & $0.022)$ & ations & \\
\hline & $\begin{array}{l}\text { pson's inver } \\
\text { 6) stations }\end{array}$ & $\operatorname{dex}$ & referen & ce statior & $\mathrm{s}$ is sign & antly & igher $t$ & Ian that & at the 10 & $p=0$ & 9) and & $10 \mathrm{~m}($ & \\
\hline${ }^{\mathrm{e}} \mathrm{E}$ & nness at refe & e stó & ions is 1 & wer thar & that at & $0 \mathrm{~m}$ & $=0.001$ & and -1 & $0 \mathrm{~m}(\mathrm{p}=$ & 8) stć & ons an & igher & the \\
\hline & station than & le 10 & $\mathrm{n}(\mathrm{p}=0$ & 011) and & $25 \mathrm{~m}(\mathrm{p}$ & 011) & tations & & & & & & \\
\hline${ }^{\mathrm{f}} \mathrm{Si}$ & oson's invers & dex a & the refe & rence sta & tions is & r tha & that at & he 0 & tation & 0.01 & & & \\
\hline
\end{tabular}

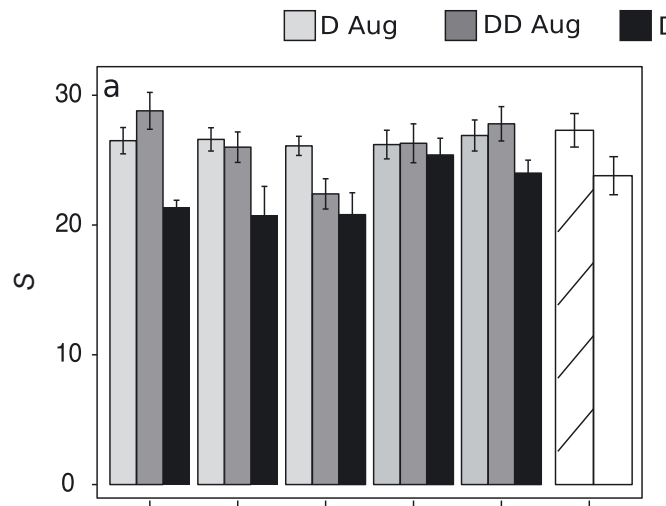

DD Oct $\square$ R Aug $\square$ R Oct
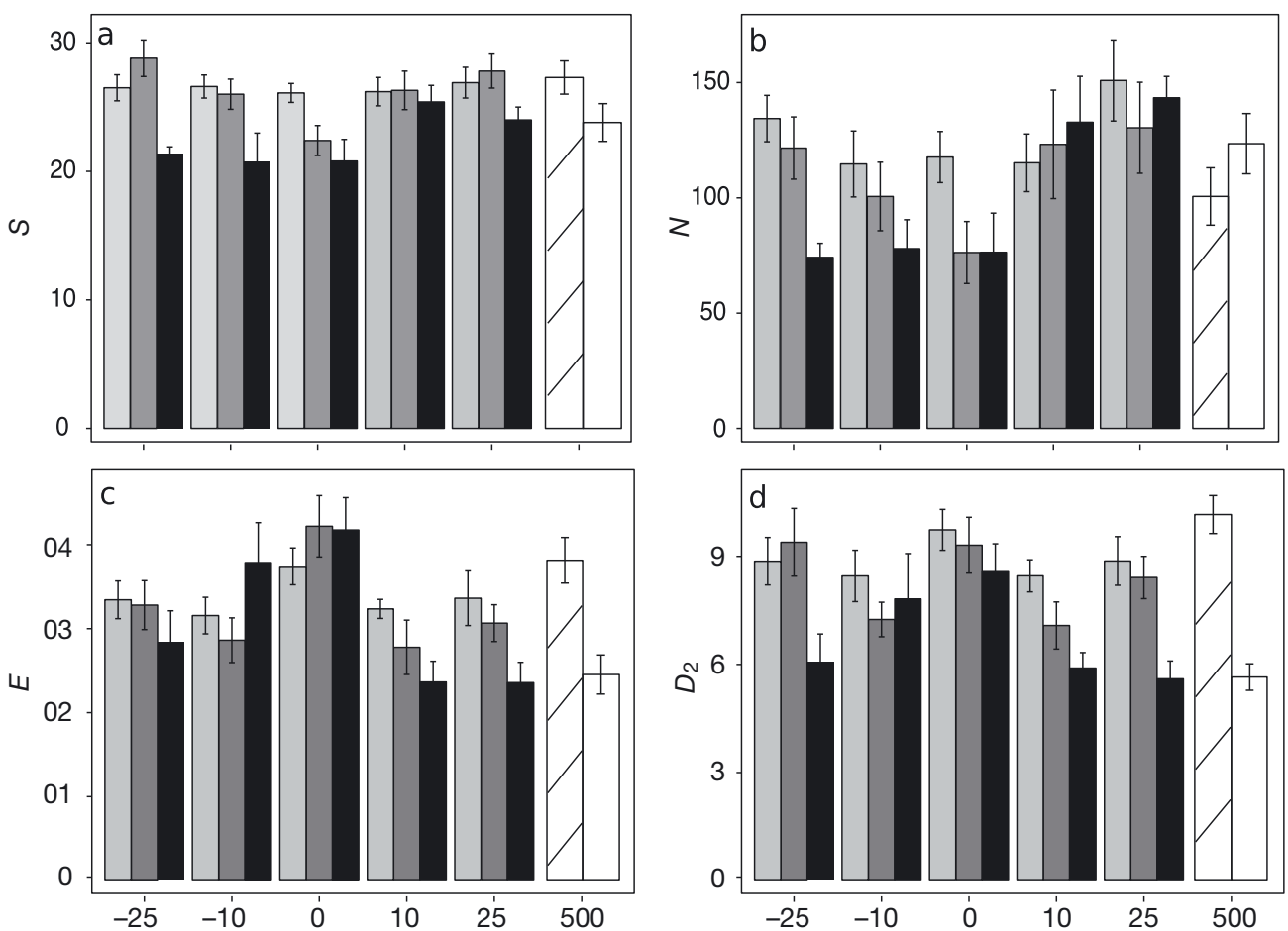

Distance $(\mathrm{m})$

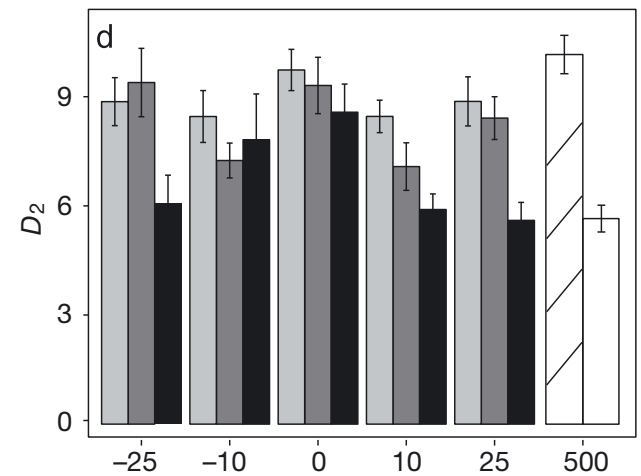

Fig. 5. Mean $( \pm \mathrm{SE})(\mathrm{a})$ number of taxa $(S)$, (b) abundance $\left(N\right.$ in ind. $\left.78.5 \mathrm{~cm}^{-2}\right)$, (c) evenness $(E)$ and (d) Simpson's inverse index $\left(D_{2}\right)$ recorded along transects under standard (D) and double density (DD) longlines and at reference stations (R), in August and October 2013 (only DD and R in October) 
Table 5. Results of PERMANOVAs testing the effect of distance on community structure for 2 densities of mussels (D: standard; DD: double) in August and October 2013. Significant values in highlighted in bold

\begin{tabular}{|c|c|c|c|c|c|c|c|c|c|c|c|}
\hline \multirow[t]{2}{*}{ Source of variation } & \multicolumn{4}{|c|}{ Aug D - } & \multicolumn{3}{|c|}{ Aug DD } & \multicolumn{4}{|c|}{ Oct DD } \\
\hline & $\mathrm{df}$ & SS & $F$ & $\mathrm{p}$ & $\mathrm{SS}$ & $F$ & $\mathrm{p}$ & $\mathrm{df}$ & SS & $F$ & $\mathrm{p}$ \\
\hline Distance & 5 & 1.275 & 2.901 & $<0.001^{\mathrm{a}}$ & 1.922 & 3.413 & $<\mathbf{0 . 0 0 1}^{\mathrm{b}}$ & 5 & 1.600 & 4.037 & $<0.001^{\mathrm{c}}$ \\
\hline Residuals & 54 & 4.744 & & & 6.083 & & & 29 & 2.299 & & \\
\hline \multirow{2}{*}{\multicolumn{12}{|c|}{$\begin{array}{l}\text { a No significant difference between reference stations }(\mathrm{p}=0.624) \text {; reference stations differed from all other distances }(\mathrm{p}< \\
0.05) ; 65 \% \text { of difference among stations along transects }(\mathrm{p}<0.05)\end{array}$}} \\
\hline \multirow{2}{*}{\multicolumn{12}{|c|}{$\begin{array}{l}{ }^{6} \text { No significant difference between reference stations }(p=0.598) \text {; reference stations differed from all other distances }(p< \\
0.05) \text { except } 25 \mathrm{~m}(\mathrm{p}>0.1) ; 55 \% \text { difference among stations along transects }(\mathrm{p}<0.05)\end{array}$}} \\
\hline & & & & & & & & & & & \\
\hline \multicolumn{12}{|c|}{${ }^{\mathrm{C} N o}$ significant difference between reference stations $(\mathrm{p}=0.779)$; reference stations differed from all other distances $(\mathrm{p}<$} \\
\hline
\end{tabular}

characteristics, and currents) and husbandry practices (culture density and depth) (Chamberlain et al. 2001, Hartstein \& Stevens 2005, Miron et al. 2005). Open-ocean farms are typically established in deep areas and cover great surface areas, which may thus result in very different dispersal patterns and environmental impacts compared to farms in coastal and more sheltered areas. To the best of our knowledge, environmental effects of these farms are very poorly documented, presumably a function of so few of such farms being operational. This study contributes to the filling of this knowledge gap through the provision of baseline information on the effect of an offshore mussel farm on sedimentation rates and macro-infaunal communities in Îles-de-la-Madeleine, eastern Canada.

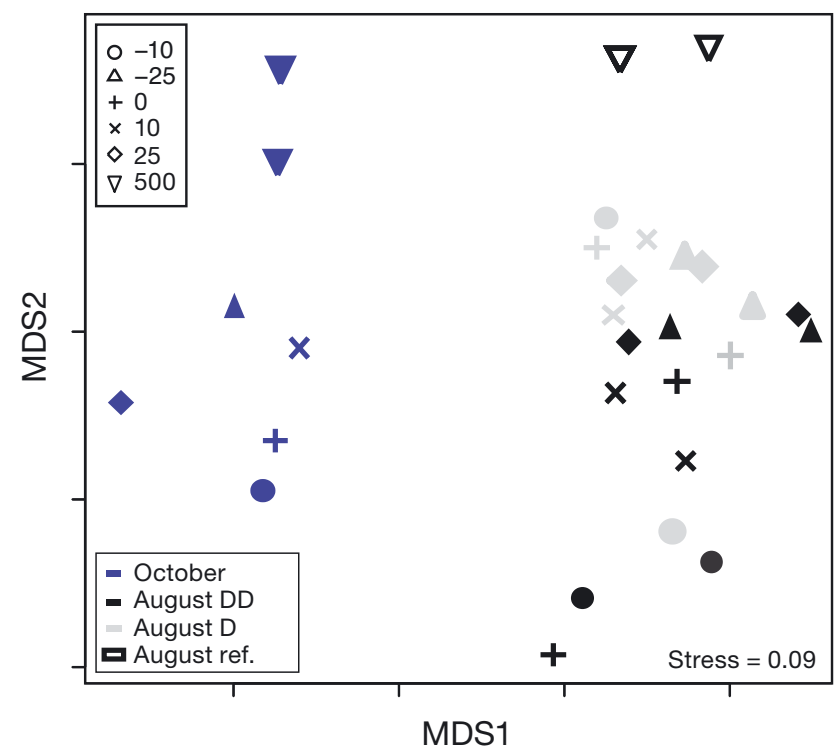

Fig. 6. Non-metric multidimensional scaling plot (data were pooled for each station along each transect) of community structure at 5 distances $(-25,-10,0,10$ and $25 \mathrm{~m})$ along transects leading away from mussel longlines of 2 densities (standard and double density) and reference stations in August and October 2013

\section{Sedimentation rates and biodeposition}

Sedimentation rates, in terms of total and organic particulate material, differed among sampling dates (higher in June), but values were relatively low and similar between farm and reference stations in October. Sedimentation rates in August and October were in the lower range of those observed in more sheltered and shallower areas. Callier et al. (2006) recorded sedimentation rates averaging between 56 and $26 \mathrm{~g} \mathrm{~m}^{-2} \mathrm{~d}^{-1}$ directly below mussel lines and along transects leading away from them, respectively, and Weise et al. (2009) reported values of ca. $103 \mathrm{~g} \mathrm{~m}^{-2} \mathrm{~d}^{-1}$ within a mussel farm. This supports the hypothesis that benthic impacts of open-ocean farms are likely limited compared to those in less exposed areas, due to the greater depth and stronger hydrodynamic conditions that characterize those farms. Biodeposit production was measured to estimate the potential contribution of the farm to sedimentation. Results were in agreement with values measured for Mytilus edulis in the field by Cranford \& Hill (1999) $\left(<80 \mathrm{mg} \mathrm{d}^{-1} \mathrm{~g}^{-1} \mathrm{DW}\right)$ and Callier et al. (2006) (18-114 $\left.\mathrm{mg} \mathrm{d}^{-1} \mathrm{~g}^{-1} \mathrm{DW}\right)$. Considering the farm area $\left(2.5 \mathrm{~km}^{2}\right)$ and the longline density (i.e. 38 ind. $\mathrm{m}^{-2}$ ), an average of $1 \mathrm{~g} \mathrm{~d}^{-1} \mathrm{~m}^{-2}$ of biodeposits could have reached the seafloor at the farm site each day, which is far less than the sedimentation rates recorded within the traps. Moreover, the organic content measured in sediment (ca. $5 \%$ ) is lower than that of biodeposits (ca. 19\%), indicating that biodeposits contribute only slightly to measured sedimentation. Sediment traps provide a measure of the gross sedimentation, which may include a significant proportion of resuspended material that is either locally derived or transported from elsewhere by currents. Additional biodeposition of organisms associated with farmed mussels (i.e. epibionts) may also contribute to the deposition of organic matter to the sea 
Table 6. Partial results of SIMPER analysis showing the pairwise comparison between the 0 m station and reference stations (500) for the double (DD) and standard (D) densities in August 2013. Cumul. sum: cumulative contributions to dissimilarities among stations. Taxa in bold are the most abundant

\begin{tabular}{|c|c|c|c|c|c|c|c|}
\hline \multirow{3}{*}{ Taxon } & \multicolumn{3}{|c|}{$-\mathrm{DD}$} & \multirow{3}{*}{ Taxon } & \multicolumn{3}{|c|}{$\longrightarrow$ D } \\
\hline & \multicolumn{2}{|c|}{ Avg. abund. } & \multirow[t]{2}{*}{ Cumul. sum } & & \multicolumn{2}{|c|}{ Avg. abund. } & \multirow[t]{2}{*}{ Cumul. sum } \\
\hline & 0 & 500 & & & 0 & 500 & \\
\hline Ninoe nigripes & 4 & 17 & 0.13 & Spiophanes bombyx & 24 & 16 & 0.14 \\
\hline Spiophanes bombyx & 14 & 16 & 0.24 & Nematoda & 14 & 8 & 0.25 \\
\hline Echinoidea & 11 & 2 & 0.33 & Echinoidea & 13 & 2 & 0.37 \\
\hline Nematoda & 9 & 8 & 0.42 & Ninoe nigripes & 11 & 17 & 0.45 \\
\hline Diastylis polita & 1 & 7 & 0.48 & Podocopida & 9 & 8 & 0.51 \\
\hline Podocopida & 6 & 8 & 0.54 & Pholoe longa & 7 & 5 & 0.55 \\
\hline Pholoe longa & 2 & 5 & 0.59 & Diastylis polita & 5 & 7 & 0.59 \\
\hline Ensis sp. & 1 & 5 & 0.63 & Ensis sp. & 3 & 4 & 0.63 \\
\hline Ilyanassa trivittata & 3 & 0 & 0.65 & Thraciidae & 1 & 3 & 0.65 \\
\hline Thraciidae & 0 & 3 & 0.68 & Nucula delphinodonta & 2 & 3 & 0.67 \\
\hline Phyllodoce mucosa & 2 & 2 & 0.70 & Phyllodoce mucosa & 2 & 2 & 0.69 \\
\hline Nucula delphinodonta & 1 & 3 & 0.72 & Sthenelais sp. & 3 & 2 & 0.72 \\
\hline
\end{tabular}

bottom at the mussel lease (Lacoste \& GaertnerMazouni 2015 and references therein), although there was no substantial fouling on the studied mussels (C. W. McKindsey pers. obs.). The gap between predicted (largely derived from biodeposition values, e.g. Giles et al. 2009, McKindsey et al. 2009, Weise et al. 2009), and recorded sedimentation rates remains a source of uncertainty in biodeposition/impact models (Grant et al. 2005). A complete examination of the composition of sedimenting material (i.e. identifying and fractioning mussel- and non-mussel-derived sources) as well as biodeposit degradation rates in the water column and at the bottom (e.g. Zúniga et al. 2014) is required to progress in the prediction of the sedimentation around aquaculture facilities.

\section{Estimated dispersion of mussel biodeposits}

Considering the mean current velocity value between June and October $\left(8.5 \mathrm{~cm} \mathrm{~s}^{-1}\right.$; data from Guyondet et al. 2015) and a biodeposit settling velocity of 0.3 to $1 \mathrm{~cm} \mathrm{~s}^{-1}$, we estimated that biodeposits from mussels at $10.5 \mathrm{~m}$ depth may have dispersed over a distance of 89 to $298 \mathrm{~m}$ around mussel lines, which may explain the lack of consistent differences observed between stations directly below and immediately around the mussel lines. We calculated that biodeposit dispersion did not exceed distances greater than $500 \mathrm{~m}$ from the farm, except for when current speeds were greater than $15 \mathrm{~cm} \mathrm{~s}^{-1}$, which only occurred on 3 days during the whole period (daily mean value). Consequently, the reference stations were likely not impacted by the mussel lines. Thus, the similar sedimentation rates recorded at the reference stations and the low \%OM observed in sediment traps seem to indicate that biodeposits are either dispersed elsewhere or are progressively degraded in the water column, as suggested in other deep bivalve aquaculture sites (Hartstein \& Stevens 2005, Lacoste \& Gaertner-Mazouni 2016), and/or that sedimented material collected in bottom traps mainly results from resuspension. Several studies have found that organic compounds of feces are strongly affected by degradation processes as more labile components are rapidly released to the environment (Giles \& Pilditch 2006, Carlsson et al. 2010, Jansen et al. 2012).

While the influence of offshore mussel farms may extend over larger areas than those of sheltered coastal farm sites (Hartstein \& Stevens 2005, Callier et al. 2006, Giles et al. 2009), our results suggest that benthic effects (due to biodeposition) are weak. This is confirmed by the low sediment organic matter content and low sulfide concentrations recorded during the experiment. Sulfides are produced from the decomposition of organic matter and levels above $1500 \mu \mathrm{m}$ are generally indicative of a transition from oxic to hypoxic conditions (Hargrave et al. 2008). In our study, surficial sediment sulfide levels are indicative of oxic conditions and natural benthic enrichment (Hargrave et al. 2008), both under the longlines and at reference stations. However, given the bottom characteristics of the site (mainly sandy), the higher TFS values recorded under the longlines (up to $800 \mu \mathrm{m}$ for some replicates) may be indicative of oxygen depletion (Cranford et al. 2017), potentially accounting for the somewhat impacted benthic communities in the vicinity of the longlines. 


\section{Benthic community indices}

The impact on benthic community characteristics was limited to samples taken directly under the DD mussel line, relative to samples from the reference stations, and did not reveal an obvious pattern of organic enrichment that could be observed in impacted farm areas where benthic macrofaunal communities have been severely affected (Dahlbäck \& Gunnarsson 1981, Stenton-Dozey et al. 2001). This result supports the observations by Tita \& Bourque (2007), who did not detect a detrimental effect of the experimental mussel farm activity on local benthic communities. In contrast to the observations of Tita \& Bourque $(2002,2007)$, we observed significantly greater abundances of some infaunal taxa, particularly polychaetes. The abundance of Spiophanes bombyx and Ninoe nigripes in their study was estimated to be in the range of 40 to 280 ind. $\mathrm{m}^{-2}$ and 360 to 740 ind. $\mathrm{m}^{-2}$, respectively, whereas we recorded $>1700 \mathrm{~S}$. bombyx $\mathrm{m}^{-2}$ and up to $3000 \mathrm{~N}$. nigripes $\mathrm{m}^{-2}$. This greater abundance may be explained by these populations being stimulated by a low but continuous farm-related organic enrichment. However, the observed organic matter content of sedimented material did not support this hypothesis, and the same range of abundances was recorded at the reference stations. These differences are therefore more likely linked with natural inter-annual fluctuations of local benthic communities.

\section{Benthic community structure}

A more holistic analysis of benthic community composition allowed us to identify a possible, although low, impact of the farm. Multivariate community composition differed between reference stations and mussel site stations on each sampling date. Some taxa known to be very sensitive to organic enrichment, i.e. Diastylis polita, Nucula delphinodonta and Thraciidae spp. (Borja et al. 2000), were observed at lower abundances at the $0 \mathrm{~m}$ station compared with stations outside of the lease. Only 2 taxa were systematically observed at greater abundances under the mussel lines or at other mussel farm stations (Ilyanassa trivittata and Echinoidea); both taxa are known to be carnivores and scavengers. Other taxa whose development may be stimulated by organic enrichment, such as Nematoda and $S$. bombyx, showed contrasting patterns, being more abundant either at the $0 \mathrm{~m}$ station or at reference stations. Likewise, organic loading was not sufficient to increase the abundance of first-order opportunistic species (e.g. Capitella), which further confirms the low impact of the farm on infaunal communities. The additional organic loading directly under mussel lines may have been sufficient to negatively impact organisms that are classified as being sensitive to organic enrichment but insufficient to stimulate those that could profit from it. Some species may also have benefited by the abundant prey that fell from the lines while being indifferent to the organic conditions. Macrofauna such as crabs, lobsters and seastars were much more abundant in the farm site than outside of it (A. S. Sean pers. comm.), as has already been shown by Clynick et al. (2008), D'Amours et al. (2008) and more recently by Drouin et al. (2015).

The heightened variability of community structure among stations under and around mussel lines (along transects) relative to that observed at reference stations likely indicates small, line-scale disturbance within the farm. As observed by Callier et al. (2008), community structure is more homogeneous further from the farm than under the lines. Increased heterogeneity related to disturbance is well known. Warwick \& Clarke (1993) recorded increased variability of community structure (beta diversity) in disturbed sites compared to control sites due to increased variability in species abundances and identities. They concluded that increased beta diversity might be used as a diagnostic tool for disturbed areas. This is supported by Séguin et al. (2014), who suggest that a change in variability of community structure could not only be an indicator of stressed communities but could also be used as an early warning signal of a critical system transition. In the present study, biodeposition rates under mussel lines may have been heterogeneous and induced variable benthic responses. Such heterogeneity or 'patchy' effects may be linked to the mussels clumping on the lines and to the small-scale variations of currents, which create heterogeneous release and deposition of particles from the water column toward the bottom. It is recommended that sampling design consider such small-scale effects as well as the larger spatial variations when monitoring the potential impacts of offshore mussel farms.

Finally, differences in community composition between August and October also highlight the importance of temporal variation, likely due to environmental conditions, on the structuring of the benthic diversity. The more homogeneous community composition along the DD transect in October suggests that communities may recover slowly after a redistribution of sediment following bad weather conditions. 


\section{CONCLUSIONS}

This study, performed 6 yr after the installation of the farm, indicates that offshore mussel culture has a limited impact on organic enrichment and macroinfaunal communities in Îles-de-la-Madeleine, where hydrological conditions and depth play a fundamental role in the dynamics of biodeposit dispersion and accumulation. There was no sign of organic enrichment, or a significantly modified environment. However, some species were probably negatively affected by the farm-derived biodeposition, while others benefited from fall-off of mussels and associated communities, which induce differences in community composition between stations under longlines and reference areas, where communities were more homogeneous. Any impacts due to organic loading from farmed mussels is very diffuse and likely limited to an area $300 \mathrm{~m}$ around the farm, as calculated by the extent of potential biodeposit dispersion. Although this 1 yr study might not be sufficient to fully evaluate the effects of offshore mussel culture, the results of this work represent a useful tool for the monitoring of the potential environmental impact of mussel farms to ensure the sustainable development of mussel culture in Canadian offshore waters.

Acknowledgements. We thank Pauline Robert, Matthieu Huot, François Roy, Paul Robichaud, Lisa Tréau de Coeli and Isabelle Lévesque for their participation with field and lab work. We also thank Thomas Guyondet for providing ADCP data. This work was supported by Fisheries and Oceans Canada (ACRDP - Aquaculture Collaborative Research and Development Programme, and PARR - Program for Aquaculture Regulatory Research), Ressources Aquatiques Québec (RAQ), MERINOV, and the Fond de Recherche du Québec - Nature et Technologies (FRQNT). Comments by four anonymous reviewers helped to improve the manuscript.

\section{LITERATURE CITED}

Aguado-Giménez F, García-García B (2004) Assessment of some chemical parameters in marine sediments exposed to offshore cage fish farming influence: a pilot study. Aquaculture 242:283-296

Anderson M, Gorley R, Clarke K (2008). PERMANOVA+ for PRIMER: guide to software and statistical methods. PRIMER-E, Plymouth

Borja A, Franco J, Perez V (2000) A marine biotic index to establish the ecological quality of soft-bottom benthos within European estuarine and coastal environments. Mar Pollut Bull 40:1100-1114

Bourque F, Myrand B (2014) Potentiel de production mytilicole en milieu ouvert aux Îles-de-la-Madeleine. MerinovRapport de recherche développement no14-09

Callier MD, Weise AM, McKindsey CW, Desrosiers G (2006)
Sedimentation rates in a suspended mussel farm (GreatEntry Lagoon, Canada): biodeposit production and dispersion. Mar Ecol Prog Ser 322:129-141

* Callier MD, McKindsey CW, Desrosiers G (2007) Multi-scale spatial variations in benthic sediment geochemistry and macrofaunal communities under a suspended mussel culture. Mar Ecol Prog Ser 348:103-115

* Callier MD, McKindsey CW, Desrosiers G (2008) Evaluation of indicators used to detect mussel farm influence on the benthos: two case studies in the Magdalen Islands, Eastern Canada. Aquaculture 278:77-88

* Callier MD, Richard M, McKindsey CW, Archambault P, Desrosiers G (2009) Responses of benthic macrofauna and biogeochemical fluxes to various levels of mussel biodeposition: an in situ 'benthocosm' experiment. Mar Pollut Bull 58:1544-1553

* Carlsson MS, Glud RN, Petersen JK (2010) Degradation of mussel (Mytilus edulis) fecal pellets released from hanging long-lines upon sinking and after settling at the sediment. Can J Fish Aquat Sci 67:1376-1387

*Chamberlain J, Fernandes TF, Read P, Nickell TD, Davies IM (2001) Impacts of biodeposits from suspended mussel (Mytilus edulis L.) culture on the surrounding surficial sediments. ICES J Mar Sci 58:411-416

Clarke KR (1993) Non-parametric multivariate analyses of changes in community structure. Aust J Ecol 18:117-143

Clarke KR, Warwick RM (2001) An approach to statistical analysis and interpretation. Changes in marine communities. PRIMER Ltd, Plymouth

Clynick BG, McKindsey CW, Archambault P (2008) Distribution and productivity of fish and macroinvertebrates in mussel aquaculture sites in the Magdalen islands (Québec, Canada). Aquaculture 283:203-210

* Cranford PJ, Hill PS (1999) Seasonal variation in food utilization by the suspension-feeding bivalve molluscs Mytilus edulis and Placopecten magellanicus. Mar Ecol Prog Ser 190:223-239

* Cranford PJ, Hargrave BT, Doucette LI (2009) Benthic organic enrichment from suspended mussel (Mytilus edulis) culture in Prince Edward Island, Canada. Aquaculture 292:189-196

* Cranford PJ, Brager L, Wong D (2017) A dual indicator approach for monitoring benthic impacts from organic enrichment with test application near Atlantic salmon farms. Mar Pollut Bull 124:258-265

* D'Amours O, Archambault P, McKindsey CW, Johnson LE (2008) Local enhancement of epibenthic macrofauna by aquaculture activities. Mar Ecol Prog Ser 371:73-84

* Dahlbäck B, Gunnarsson L (1981) Sedimentation and sulfate reduction under a mussel culture. Mar Biol 63:269-275

* Danovaro R, Gambi C, Luna GM, Mirto S (2004) Sustainable impact of mussel farming in the Adriatic Sea (Mediterranean Sea): evidence from biochemical, microbial and meiofaunal indicators. Mar Pollut Bull 49:325-333

* Dimitriou PD, Karakassis I, Pitta P, Tsagaraki TM and others (2015) Mussel farming in Maliakos Gulf and quality indicators of the marine environment: good benthic below poor pelagic ecological status. Mar Pollut Bull 101:784-793

* Drouin A, Archambault P, Clynick B, Richer K, McKindsey CW (2015) Influence of mussel aquaculture on the distribution of vagile benthic macrofauna in Iles de la Madeleine, eastern Canada. Aquacult Environ Interact 6:175-183

Fabi G, Manoukian S, Spagnolo A (2009) Impact of an opensea suspended mussel culture on macrobenthic commu- 
nity (Western Adriatic Sea). Aquaculture 289:54-63

FAO (2016) The state of world fisheries and aquaculture. Contributing to food security and nutrition for all. FAO, Rome

Forrest BM, Keeley NB, Hopkins GA, Webb SC, Clement DM (2009) Bivalve aquaculture in estuaries: review and synthesis of oyster cultivation effects. Aquaculture 298: $1-15$

Froehlich HE, Smith A, Gentry R, Halpern B (2017) Offshore aquaculture: I know it when I see it. Front Mar Sci 4:1-9

Gaertner-Mazouni N, Lacoste E, Bodoy A, Peacock L and others (2012) Nutrient fluxes between water column and sediments: potential influence of the pearl oyster culture. Mar Pollut Bull 65:500-505

Gentry RR, Lester SE, Kappel CV, White C, Bell TW, Stevens J, Gaines SD (2017) Offshore aquaculture: spatial planning principles for sustainable development. Ecol Evol 7:733-743

Giles H, Pilditch CA (2006) Effects of mussel (Perna canaliculus) biodeposit decomposition on benthic respiratioin and nutrient fluxes. Mar Biol 150:261-271

* Giles H, Broekhuizen N, Bryan KR, Pilditch CA (2009) Modelling the dispersal of biodeposits from mussel farms: the importance of simulating biodeposit erosion and decay. Aquaculture 291:168-178

Grant J, Cranford P, Hargrave B, Carreau M, Schofield B, Armsworthy S, Burdett-Coutts V, Ibarra D (2005) A model of aquaculture biodeposition for multiple estuaries and field validation at blue mussel (Mytilus edulis) culture sites in eastern Canada. Can J Fish Aquat Sci 62:1271-1285

Grizzle RE, Ward LG, Fredriksson DW, Irish JD and others (2014) Long-term seafloor monitoring at an open ocean aquaculture site in the western Gulf of Maine, USA: development of an adaptive protocol. Mar Pollut Bull 88:129-137

Guyondet T, Mckindsey CW, Bourque F, Drouin A, Nadeau M (2015) Production carrying capacity assessment for offshore mussel culture development in Îles de la Madeleine (Québec, Canada). Can Tech Rep Fish Aquat Sci 3148. Fisheries and Oceans Canada, Moncton

Hargrave BT, Doucette LI, Cranford PJ, Law BA, Milligan TG (2008) Influence of mussel aquaculture on sediment organic enrichment in a nutrient-rich coastal embayment. Mar Ecol Prog Ser 365:137-149

Hartstein ND, Stevens CL (2005) Deposition beneath longline mussel farms. Aquacult Eng 33:192-213

Holmer M (2010) Environmental issues of fish farming in offshore waters: perspectives, concerns and research needs. Aquacult Environ Interact 1:57-70

* Jansen HM, Verdegem MCJ, Strand Ø, Smaal AC (2012) Seasonal variation inmineralization rates (C-N-P-Si) of mussel Mytilus edulis biodeposits. Mar Biol 159:1567-1580

Jansen HM, Burg S, Bolman B, Jak RG, Kamermans P, Poelman M, Stuiver M (2016) The feasibility of offshore aquaculture and its potential for multi-use in the North Sea. Aquacult Int 24:735-756

Koutitonsky VG, Navarro N, Booth D (2002) Descriptive physical oceanography of Great-Entry lagoon, Gulf of St. Lawrence. Estuar Coast Shelf Sci 54:833-847

* Lacoste E, Gaertner-Mazouni N (2015) Biofouling impact on production and ecosystem functioning: a review for bivalve aquaculture. Rev Aquacult 7:187-196

Lacoste E, Gaertner-Mazouni N (2016) Nutrient regeneration in the water column and at the sediment-water

Editorial responsibility: Marianne Holmer,

Odense, Denmark interface in pearl oyster culture (Pinctada margaritifera) in a deep atoll lagoon (Ahe, French Polynesia). Estuar Coast Shelf Sci 182:304-309

Lomax RG, Hahs-Vaughn DL (2013) An introduction to statistical concepts. A second course. Routledge, New York, NY

* Mallet A, Carver C, Landry T (2006) Impact of suspended and off-bottom Eastern oyster culture on the benthic environment in eastern Canada. Aquaculture 255:362-373

*McKindsey CW, Lecuona M, Huot M, Weise AM (2009) Biodeposit production and benthic loading by farmed mussels and associated tunicate epifauna in Prince Edward Island. Aquaculture 295:44-51

* McKindsey CW, Archambault P, Callier MD, Olivier F (2011) Influence of suspended and off-bottom mussel culture on the sea bottom and benthic habitats: a review. Can J Zool 89:622-646

McKindsey CW, Archambault P, Simard N (2012) Spatial variation of benthic infaunal communities in baie de Gaspé (eastern Canada) - influence of mussel aquaculture. Aquaculture 356-357:48-54

* Miron G, Landry T, Archambault P, Frenette B (2005) Effects of mussel culture husbandry practices on various benthic characteristics. Aquaculture 250:138-154

Newell RI (2004) Ecosystem influences of natural and cultivated populations of suspension-feeding bivalve molluscs: a review. J Shellfish Res 23:51-62

Pearson TH, Rosenberg R (1978) Macrobenthic succession in relation to organic enrichment and pollution of the marine environment. Oceanogr Mar Biol Annu Rev 16:229-311

Quinn GP, Keough MJ (2002) Experimental design and data analysis for biologists. Cambridge University Press, Cambridge

Séguin A, Gravel D, Archambault P (2014) Impact of disturbance regimes on alpha and beta diversity of rock pools. Diversity (Basel) 6:1-17

Stenton-Dozey J, Probyn T, Busby A (2001) Impact of mussel (Mytilus galloprovincialis) raft-culture on benthic macrofauna, in situ oxygen uptake, and nutrient fluxes in Saldanha Bay, South Africa. Can J Fish Aquat Sci 58: 1021-1031

Tita G, Bourque F (2007) Évaluation environnementale d'un site mytilicole expérimental dans la baie de Plaisance, Îles-de-la-Madeleine. MAPAQ - Rapport de recheche et développement no 158

Warwick RM, Clarke KR (1993) Increased variability as a symptom of stress in marine communities. J Exp Mar Biol Ecol 172:215-226

Wheise AM, Cromey CJ, Callier MD, Archambault P, Chamberlain J, McKindsey CW (2009) Shellfish-DEPOMOD: modelling the biodeposition from suspended shellfish aquaculture and assessing benthic effects. Aquaculture 288:239-253

Werstink (2007) Évaluation du potentiel conchylicole des Îles-de-la-Madeleine (Québec, Canada): une analyse multicritères combinée à un système informatique géographique. Mémoire de maitrise, Université du Québec à Rimouski

* Zúñiga D, Castro CG, Aguiar E, Labarta U, Figueiras FG, Fernández-Reiriz MJ (2014) Biodeposit contribution to natural sedimentation in a suspended Mytilus galloprovincialis Lmk mussel farm in a Galician Ría (NW Iberian Peninsula). Aquaculture 432:311-320

Submitted: February 22, 2018; Accepted: August 26, 2018

Proofs received from author(s): October 26, 2018 